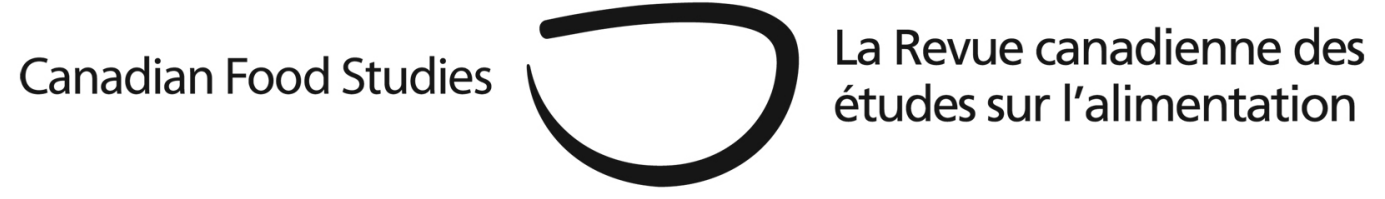

Original Research Article

\title{
Access and affordability of "healthy" foods in northern Manitoba? The need for Indigenous food sovereignty
}

\author{
Mengistu Assefa Wendimu, Annette Aurélie Desmarais*, Tabitha Robin Martens \\ University of Manitoba
}

\begin{abstract}
Despite widespread concerns about household food insecurity experienced by Indigenous peoples, there is limited empirical evidence about the availability and prices of healthy foods in First Nations rural communities located in northern Manitoba, Canada. To fill this research gap, this study examines the availability and affordability of fresh milk, fruits, vegetables, and several other selected food items; investigates the determinants of food prices; and examines the implications of paying higher food prices for individuals and communities in northern Manitoba. The research findings are based on a survey of fifty-two food items conducted in twenty-two communities and six focus group discussions with mothers, service providers, and community leaders. Our research indicates that in addition to limited availability of healthy foods, food prices in First Nations communities were significantly higher than in Winnipeg or non-First Nations urban centers. We conclude by pointing to some policy implications emerging from this research while also signaling the need for a more substantial and profound transformation that includes decolonizing food systems and building Indigenous food sovereignty.
\end{abstract}

Keywords: High food prices; Indigenous communities; Indigenous food sovereignty 


\section{Introduction}

In 2012, approximately 4 million Canadians (12.6 percent) experienced some level of household food insecurity while the rate of food insecurity among Indigenous peoples was about 28.2 percent (Tarasuk, Mitchell, \& Dachner, 2014). ${ }^{1}$ A survey conducted with 534 households living on reserve in northern Manitoba also found that 75 percent of the survey participant households were food insecure (Fieldhouse \& Thompson, 2012; Thompson et al., 2011). Following his Mission to Canada in 2012, the UN Special Rapporteur on the right to food, expressed deep concern about the severe food insecurity experienced by Indigenous peoples living on and off reserves, and in rural and urban areas (De Schutter, 2012). The Council of Canadian Academies Expert Panel that assessed Aboriginal peoples’ food security status in northern Canada also stressed that food insecurity is a significant public health concern for Indigenous peoples that needs urgent attention (Council of Canadian Academies, 2014).

Though food insecurity is not a new problem, how it is currently experienced by Indigenous peoples in northern Canada differs from past experiences of fluctuating food supplies (Council of Canadian Academies, 2014). Contemporary food insecurity, as experienced by Indigenous peoples in Canada, is shaped by a long history and the ongoing processes and legacies of colonization, unresolved treaty processes, environmental dispossession and displacement, rapid environmental change, logistical challenges, changing food knowledge and preferences, and a decline in intergenerational transfer of traditional Indigenous knowledge as a result of oppressive and colonizing forces (Council of Canadian Academies, 2014; Morrison, 2011). Since traditional Indigenous food pathways have been so dramatically altered, food insecurity among Indigenous peoples is now also exacerbated by limited access to, and high prices of, 'healthy' store-bought foods (Socha, Zahar, Chambers, Abraham, \& Fiddler, 2012; Willows, 2005). ${ }^{2}$

Despite a widespread concern about the lack of food availability and high food prices, there is limited empirical evidence about the availability and prices of healthy foods in First Nations rural communities in northern Manitoba. To fill this research gap, our study examined the availability and affordability (prices) of fresh milk, fruits, vegetables, and several other selected food items; investigated the determinants of food prices; and examined the implications of paying higher food prices for individuals and communities. We begin by presenting a brief

\footnotetext{
${ }^{1}$ Food security is most commonly defined as "exist[ing] when all people, at all times, have physical and economic access to sufficient, safe and nutritious food to meet their dietary needs and food preferences for a healthy and productive life." (Food and Agriculture Organization of the United Nations [FAO], 1996). Food insecurity occurs when these conditions are not achieved. See the FAO's (2006) policy brief for a detailed discussion of the four key dimensions of food security: availability, access, utilization and stability.

${ }^{2}$ In this paper, we are using Canada's Food Guide (Health Canada, 2007) general explanation of 'healthy' and 'less healthy' food. That is, healthy food provides recommended amounts of nutrients such as minerals, vitamins, and energy requirements to promote optimum well-being, prevent nutrient deficiency, and reduce risk of chronic disease. 'Less healthy' food and beverages are defined as those food that are high in energy density, containing saturated fat, trans fat, added sugar and salt such as potato chips, energy drinks, and pop.
} 
historical context of Indigenous peoples' food systems and the impact of colonial policies. This is followed by an explanation of the research methodology and the study communities. Next, we present the quantitative research results followed by a discussion that also includes the qualitative research findings. We conclude by highlighting some key policy implications revealed by the empirical findings.

\section{Historical context}

To more fully comprehend the current food insecurity and the related health problems experienced by Indigenous peoples in Canada, it is critical to understand Indigenous peoples' traditional food systems and the impact of colonial policies. Indigenous peoples in Canada were supported by land-based traditional foods for thousands of years before the westernization of their food systems (Haman et al., 2010). Historically, Indigenous peoples' dietary practices were highly regionally diverse and ecologically dependent. They often included varying combinations of harvesting and consuming foods from the land and water using hunting, trapping, fishing, gathering, and agriculture (Willows, 2005); some communities sourced their food primarily from animals and fish (Kuhnlein, Souedia, \& Receveur, 1996) while others depended to some degree on agriculturally produced food items such as beans, maize and squash (Kuhnlein \& Turner, 1991; Kwon, Apostolidis, Kim, \& Shetty, 2007).

For example, in northern Canada, traditional Indigenous food systems encompassed harvesting and consumption of wildlife including: moose, caribou, and beaver; smaller furbearing mammals such as rabbit, mink, marten, and muskrat; different fish varieties such as whitefish, walleye, pike, suckers, burbot, and sturgeon; and wild berries such as blueberries, raspberries, gooseberries, partridge berries, plus local herbs and roots (Robidoux, Haman, \& Sentha, 2009). Traditional foods are not only valued from health, cultural, and spiritual perspectives (Johnson, Nobmann, Asay, \& Lanier, 2009; Kamal, Linklater, Thompson, Dipple, \& Committee, 2015; Willow, 2005) but also the acquisition and distribution of traditional foods are central to practicing and strengthening cultural values through the processes of sharing and cooperation (Redwood et al., 2008).

Despite their importance, the traditional Indigenous food systems in Canada have changed significantly over time. Considerable shifts in Indigenous peoples' traditional food systems occurred in the 1800 s as a result of signing treaties that led to population aggregation into permanent settlements and the establishment of the reserve system ${ }^{3}$ (Rudolph \& McLachlan, 2013). The treaties contributed significantly to the decline of Indigenous food systems while creating long-term dependency on the government that jeopardized Indigenous peoples' food

\footnotetext{
${ }^{3}$ The term "reserve" means "any tract or tracts of land set apart by treaty or otherwise for the use or benefit of or granted to a particular band of Indians [First Nations], of which the legal title is in the Crown, but which is unsurrendered, and includes all the trees, wood, timber, soil, stone, minerals, metals, or other valuables thereon or therein” (The Indian Act, 1876).
} 
security and undermined local food initiatives (Rudolph \& McLachlan, 2013). Not only were Indigenous peoples subjected to policies of starvation (Daschuk, 2013), but reserve lands were generally of poor quality and government policies were also introduced to ensure that reserve farmers were systematically excluded by various means from the evolving agrarian economy (Carter, 1993). The imposition of private property regimes along with new land use effectively meant that Indigenous peoples no longer had access to traditional food sources (Alfred, 2009).

There is no doubt that colonial policies have had significant economic, social, cultural, and health consequences for Indigenous peoples (Alfred, 2009; Dashuk, 2013; Harris, 2002). These were exacerbated by the institutionalized assimilation of Indigenous peoples to colonial culture and tradition that was implemented by forcibly removing Indigenous children from their parents and placing them in federally funded Indian Residential Schools (Partridge, 2010). Many residential schools used food as a tool of manipulation and coercion where starvation, malnourishment, and non-consensual nutritional experimentation were present, all while children were restricted to an entirely new diet of non-traditional foods (Mosby, 2013; Truth \& Reconciliation Commission, 2015).

Because of the Indian Residential School system's enduring intergenerational negative effects on the well-being of Indigenous peoples, it is considered an act of cultural genocide and remains the source of many of the contemporary problems facing Indigenous peoples in Canada (MacDonald \& Hudson, 2012). Likewise, the establishment of permanent settlements on reserves caused changes in Indigenous peoples' lifestyle and corresponding nutritional shifts (Szathmary, Ritenbaugh, \& Goodby, 1987).

Indigenous peoples experienced the consequences of the colonization of their food systems in various ways including isolation, persistent poverty, food insecurity, dependency on government handouts (Alfred, 2009; McCallum, 2017), and the loss of traditional knowledge and skills related to harvesting and preparation of traditional foods (Glacken, 2008). The rapid shift from reliance on traditional foods to more energy dense store-bought processed foods has been also associated with the prevalence of chronic diseases among Indigenous communities in Canada (Haman et al., 2010). One of the main health consequences of the colonial induced nutritional transition is the significant rise in obesity and obesity-related diseases such as the increased occurrence of Type II diabetes and heart disease (Bruce, 2000; Haman et al., 2010; Johnson, Martin, \& Sarin, 2002; Kuhnlein et al., 1996; Reading \& Wien, 2009; Young, Reading, Elias, \& O’Neil, 2000). According to Thompson et al. (2011), Indigenous peoples in northern Manitoba have the highest rate of pediatric diabetes in northern America, which is partially explained by a lack of physical and economic access to sufficient, safe and nutritious food in the region.

Despite the grave impacts of colonization, there has been a resurgence in Indigenous peoples' food systems as well as traditional knowledge, spiritual, and cultural values (Corntassel, 2012). Corntassel (2012) describes the Indigenous resurgence as "having the courage and imagination to envision life beyond the state" (p.89). He further argues that "if colonization is a disconnecting force, then resurgence is about reconnecting with homelands, cultures, and 
communities” (p.97). Importantly, resurgence enables Indigenous peoples to renew their roles and responsibilities with the sustainable practices of Indigenous livelihoods, food security, community governance, and connections to the natural world, while also practicing traditional knowledge and skills and transferring these to the future generation (Corntassel, 2008). Simpson (2011) stresses that Indigenous resurgence is "a celebration that after everything, we are still here” (p.12) as expressed through a return to the lands, languages, and ceremonies of Indigenous peoples in Canada.

There are, however, important challenges to the processes of Indigenous resurgence (Haman et al., 2010). Regular and unimpeded access to traditional territories and a return to traditional food habits, spiritual and cultural practices are critical to Indigenous resurgence (Cidro \& Martens, 2014). Yet, more recently, Indigenous peoples’ access to their traditional territories and the availability and sustainability of traditional foods are being affected by environmental changes (Chan et al., 2010; Glacken, 2008) and growing pressure and interest in 'development' projects such as provincial and federal parks, forestry, mining, hydro, gas, and oil development (Haman et al., 2010). Haman et al. (2010) identify four key factors that may hinder or enhance the revival of traditional food systems: (1) knowledge (of traditional food harvesting, preparation, and consumption); (2) economics (e.g., costs of hunting, trapping and fishing); (3) availability/sustainability of traditional foods in local areas; and (4) access to land (e.g., for hunting, fishing, and other land-based practices). Although the resurgence of traditional food systems is absolutely key to addressing the current food insecurity and the related health issues facing Indigenous peoples, policies and programs to ensure access to affordable healthy market foods are also important, at least in the short term (Power, 2008).

\section{Research methods}

This research was approved by the Office of Research Ethics and Compliance Board at the University of Manitoba and it was conducted in collaboration with the Public Interest Law Centre (PILC) and the Manitoba Keewatinowi Okimakanak (MKO). ${ }^{4}$

The research proposal was presented and discussed at the MKO Chiefs’ General Assembly on Health that was held in April 2016 in Thompson, Manitoba. Since this event brought together chiefs, councilors, and health directors from more than 25 First Nations communities in northern Manitoba our aim was to obtain feedback from Indigenous leaders. The

\footnotetext{
${ }^{4}$ PILC is a not-for-profit organization that works with marginalized populations to assist them in realizing their legal and social rights (http://legalhelpcentre.ca/public-interest-law-centre). The MKO describes itself as "a non-profit, political advocacy organization that provides a collective voice on issues of inherent, Treaty, aboriginal and human rights for the citizens of the 30 sovereign First Nations we represent.” (http://www.mkonation.com/) We also consulted Food Matters Manitoba, a local long-standing non-governmental organization that hosts the Manitoba Food Charter and engages in food related social-justice work across the province (http://www.foodmattersmanitoba.ca/).
} 
MKO chiefs in the Assembly passed a resolution in full support of the project and made suggestions for potential study communities.

Importantly, the engagement with MKO included the full participation of Mr. Brennan Manoakeesick (an Indigenous researcher and former Housing Manager and Special Projects Advisor at MKO) who assisted in the fieldwork by identifying research communities and participants, organized all logistics for holding focus groups in the communities, and facilitated the focus group discussions. MKO’s participation also helped to expand the scope of the research as originally planned, to go beyond examining only the price of milk and include additional food items in the survey. The effective collaboration with MKO ensured that the research was relevant to MKO First Nations. The research proposal was also discussed with the leadership from Northlands Denesuline First Nation (NDFN) during a workshop organized by the University of Manitoba’s Department of Internal Medicine (Bannatyne Campus) in April 2016.

After consulting with different stakeholders, the First Nations and non-First Nations communities in this research were purposely selected considering a wide range of criteria such as community type (First Nations versus non-First Nations), year-round access to road or extent of remoteness, geographic distribution of communities across northern Manitoba, and suggestions of specific communities that we received from the MKO chiefs. Accordingly, a total of 22 communities were selected (See Figure 1 for locations and Table 1 for community names): 15 First Nations (nine communities with a year-round road access and six communities without year-round road access) and seven non-First Nations communities (four urban centers and three rural communities).

We used a comparative mixed methods research approach involving both quantitative and qualitative methods. Quantitative data were collected using an in-store food prices survey using a survey questionnaire while qualitative data were obtained through focus group discussions. The survey questionnaire listed 52 food items grouped by food types such as dairy and meat products, fresh fruit and vegetables, non-perishable food items, and food items that are considered less nutritious. At the time of the in-store food prices data collection, 67 percent of the First Nations communities visited had only one grocery store while two First Nations communities (13 percent) had none. In First Nations communities and non-First Nations urban centers in Northern Manitoba with two or more stores, we conducted the in-store price survey in at least two stores.

In total, the in-store food prices data were collected in 37 stores (13 stores in First Nations communities with year-round road access, six stores in First Nations communities with no year-round road access, seven stores in non-First Nations communities in northern Manitoba, and 11 stores in Winnipeg). All non-First Nations communities in northern Manitoba have access to all-weather roads or train. In locations where there were more than two stores, larger stores that were considered to offer a wider food selection and lower prices were selected. The data was collected in August and early September, 2016. While prices and access to food are considered to vary by season, both accessibility and prices are generally better during summer time thus the findings presented here do not overestimate the prices and food availability constraints. 
Information gathered through the focus group discussions was used to highlight the seasonal differences in food prices and availability.

Before starting the in-store food prices survey in each of the stores, permission was first obtained from store managers. In every store, food items with the lowest price were recorded. For each of the 52 food items, we recorded the brand name (if available), weight/unit, price per unit (for preferred units), and availability in the store. If the preferred unit was not available in the store, we recorded the nearest size available. In some instances when food prices were not shown on shelves, we were allowed to bring these food items to the store's checkout counter and get the price checked by store employees. If the food item on the survey list was temporarily out of stock at the time of data collection this was noted, and we recorded the price listed on the shelf or the price indicated by store employees. However, if the food item was not available in the store at all, this was recorded as NA (not available) under the price column. Where food items on the list were on sale, we recorded both the original and sale prices. The analysis presented in this report is based on the original prices because, as revealed during the focus group discussions, in First Nations communities, sales on food items are not very common.

To facilitate food prices comparisons across communities and locations, all food items were converted into a common unit of measurement (e.g., all prices per pound or grams were converted to price per kilogram). Where the First Nations communities are eligible to receive a transportation subsidy through the Nutrition North Canada (NNC) program (as was the case for six of the First Nations communities in this study), the prices after the subsidy were applied. In Manitoba, as of October 2016, 18 First Nations communities with no all-weather roads were eligible to receive a transportation subsidy through NNC program. The NNC program subsidizes perishable nutritious foods and commercially produced country (traditional) foods for eligible communities.

All the price data were entered into an excel database and analyzed using a commonly used statistical software called R statistical software. The average food prices across different locations were compared using Tukey's test for multiple comparisons of means. ${ }^{5}$ An Ordinary Least Square (OLS) regression analysis was also conducted for certain food items to identify the determinants of food prices across different geographic areas.

Qualitative data on the implications of paying higher prices for food for individuals and communities (e.g., psychological, health, and emotional effects), access to stores (e.g., transportation challenges), and monthly or seasonal variation in food availability and prices were collected through six focus group discussions that were held in the four communities of Cross Lake, Chemawawin, Wasagamack, and Lac Brochet. This included four focus group discussion with mothers, and two with community service providers (e.g., daycare teachers, social workers, and health officers) and community leaders (e.g., councilors).

\footnotetext{
${ }^{5}$ Tukey's test is a statistical test used to compare the average of every group to the averages of every other groups simultaneously. The null hypothesis in Tukey's test is that there is no difference in the groups mean.
} 
The First Nations communities that participated in the focus group discussions were selected in collaboration with MKO based on their geographic location (north west, far north, central and north east), and access to road (with and without all-weather road access). This selection was made with consideration that the information from the focus groups could reveal the various challenges faced by different First Nations communities in northern Manitoba, in relation to the availability and affordability of healthy foods. The focus group participants were selected in close collaboration with community leaders and health officers. Selection criteria were communicated with the councilors and health officers by the lead author and research assistant. To select the mothers who participated in the focus group discussion, criteria such as different age groups, economic status (i.e., employed and those on social assistance), and marital status (married and single mothers), were used. For the focus group with service providers, we selected experts from different departments. The open ended questions for the focus groups were developed beforehand with input from MKO staff. Participants often raised additional issues and these were also discussed as they arose.

As mentioned above, Brennan Manoakeesick, an Indigenous researcher with more than seven years of work with MKO and considerable research experience with First Nations communities in Manitoba, facilitated the focus group discussion. Prior to each discussion, we explained the research objectives, the estimated duration of the discussion, and the content of the consent form that included information about anonymity, confidentiality, and other ethical considerations. Once all participants had signed the consent form we proceeded. The focus group discussions were audio-recorded with full consent of the focus group participants; notes were also taken by the lead author. All the focus group participants were paid a small honorarium for taking the time to participate in the research and sharing their knowledge and experience. The audio recordings of the focus group discussions were analyzed using Nvivo 11 software.

\section{Results of quantitative research}

\section{Socio-economic characteristics of the study communities}

Before beginning to present the research results, it is important to understand some of the context of the communities under study. (See Table 1 for a presentation of the socio-economic characteristics of all the study communities except Stevenson Island, for which socio-economic data are unavailable.) These descriptive statistics demonstrate that the average median income in First Nations communities is nearly half of the average median household income of non-First Nation communities, while the unemployment rate and proportion of family income from government transfers are higher in First Nations communities than in non-First Nations communities.

In 2016, while the average unemployment rate among the First Nations communities considered for this study was 25.5 percent, it was only 5.8 percent for the non-First Nation 
communities. Similarly, the proportion of average family income from government transfers for First Nations and non-First Nations communities were 37.3 percent and 12.1 percent, respectively. Another factor that distinguished the First Nations and non-First Nations communities considered for this study was their access to all-weather roads. About 40 percent of the First Nations communities visited for this study did not have access to all-weather roads.

Figure 1: Map of the study communities

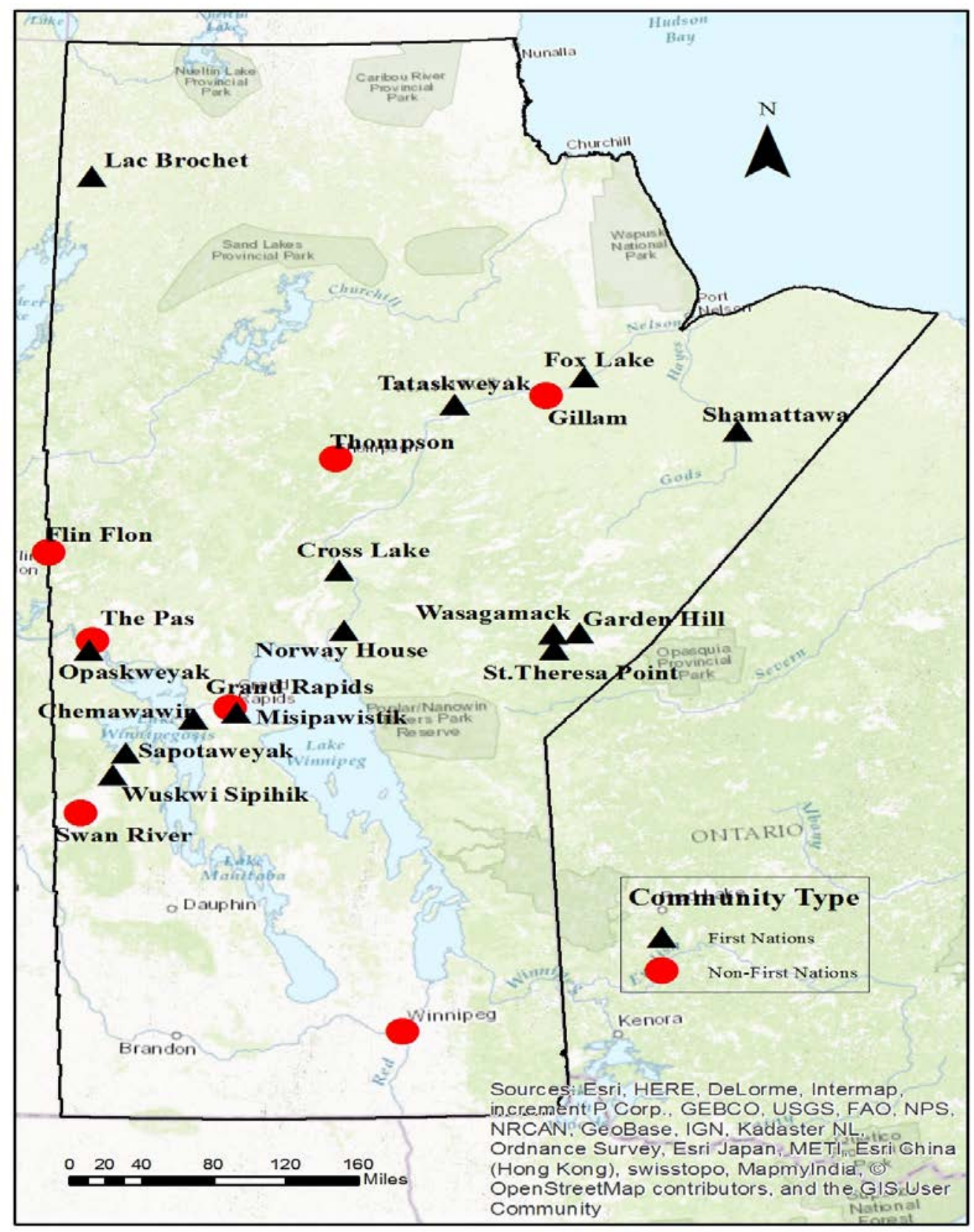




\section{Food availability}

Table 2 shows the percentage availability of selected food items at the time of data collection. Food availability here refers to whether the stores surveyed retailed the specified food items or not. All the stores surveyed in Winnipeg and non-First Nations urban centers in northern Manitoba sold almost all of the different types of milk, except lactose-free milk for which availability in all the stores visited was very limited. In rural First Nations communities with and without access to an all-weather road, skim and lactose-free milk had the lowest availability, while the availability of low-fat (1 percent), reduced-fat (2 percent) and whole (3.25 percent) milk was higher than other milk categories in these communities. Although all the 37 stores surveyed sold at least two different types of regular milk (with different container size and fat content), lactose-free milk (any container size and fat content) was unavailable in six (40 percent) of the First Nations rural communities. Lack of access to lactose-free milk due to its unavailability in these communities has direct implications on the health of people who do not consume regular milk due to lactose intolerance.

The availability of store-bought fresh meat products was very limited in rural First Nations communities with no access to an all-weather road. More than two-thirds of the stores in the rural First Nations communities without an all-weather road did not sell fresh meat products. Although there was a significant difference in terms of freshness and quality, availability of fruits and vegetables were similar across the different study communities. The availability of less healthy foods and drinks (items high in calories, fat, sugar or salt) such as potato chips, pop, and energy drinks was high and similar across the different study communities.

Of the 52 food items surveyed, two-litre milk (2 percent), eggs, and Pepsi were the only food items that were consistently available in all the 37 stores surveyed. In almost all the stores in the rural First Nations communities that we surveyed, the shelf space allocated to less healthy foods and drinks was much larger than the space allocated to fresh fruits, vegetables, and dairy products together. The less healthy food items were primarily placed on the front shelves of the stores, while the healthy food items were mostly placed on the back shelves. 
Table 1: Socio-economic characteristics of study communities

\begin{tabular}{|c|c|c|c|c|c|c|c|}
\hline Community name & $\begin{array}{l}\text { Population } \\
\text { size }\end{array}$ & $\begin{array}{c}\text { Median HH } \\
\text { income }\end{array}$ & $\begin{array}{c}\text { Government } \\
\text { transfer } \\
\text { (percent of } \\
\text { income) }\end{array}$ & $\begin{array}{l}\text { Unemploy- } \\
\text { ment rate }\end{array}$ & $\begin{array}{c}\text { Access to an } \\
\text { all-weather } \\
\text { rod }\end{array}$ & $\begin{array}{l}\text { Accessible by } \\
\text { air }\end{array}$ & $\begin{array}{c}\text { Distance } \\
\text { from } \\
\text { Winnipeg }\end{array}$ \\
\hline Lac Brochet & 1090 & 31,759 & 31 & 38.2 & No & Yes & 1090 \\
\hline Shamattawa First Nation & 1592 & 42,196 & 44 & 10.8 & No & Yes & 743 \\
\hline Tataskweyak Cree Nation & 3,837 & 35,965 & 36 & 42.4 & Yes & No & 905 \\
\hline Cross Lake Cree Nation & 8,482 & 31,745 & 33 & 22.1 & Yes & Yes & 770 \\
\hline Norway House & 7,996 & 20,800 & 33 & 28 & Yes & Yes & 806 \\
\hline Opaskwayak Cree Nation & 5,989 & 39,742 & 24 & 17.5 & Yes & No & 625 \\
\hline Chemawawin Cree Nation & 1,860 & 27,219 & 38 & 20 & Yes & No & 450 \\
\hline Misipawistik Cree Nation & 2,004 & 28,738 & 39 & 17.1 & Yes & No & 432 \\
\hline Sapotaweyak Cree Nation & 2,509 & 15,716 & 41 & 36 & Yes & No & 391 \\
\hline Garden Hill First Nations & 2,655 & 25.744 & 42 & 25.2 & No & Yes & 485 \\
\hline St. Theresa Point & 4,221 & 31,925 & 39 & 25.8 & No & Yes & 485 \\
\hline Wasagamack First Nation & 2,145 & 25,000 & 48 & 23.4 & No & No & 481 \\
\hline Grand Rapids & 720 & 28,736 & NA & NA & Yes & Yes & 432 \\
\hline Swan River & 3,750 & 39,989 & 24.9 & 3.2 & Yes & Yes & 497 \\
\hline Flin Flon & 5,520 & 69,246 & 11.9 & 5.7 & Yes & Yes & 764 \\
\hline Thompson & 12,730 & 79,162 & 5.5 & 7 & Yes & Yes & 762 \\
\hline Gillam & 1,195 & 106,043 & 4.9 & 4 & Yes & Yes & 1064 \\
\hline The Pas & 5,555 & 57,247 & 13.6 & 7.7 & Yes & Yes & 625 \\
\hline Winnipeg & 649,995 & 57,925 & 11.6 & 5.9 & Yes & Yes & NA \\
\hline Manitoba & $1,208,268$ & 57,299 & 12.5 & 6.2 & NA & NA & NA \\
\hline
\end{tabular}

Source: Compiled from websites of Indigenous and Northern Affairs Canada (2016), and Statistics Canada (2011) and Google Map (for the distance from Winnipeg). 
Table 2: Percentage of food availability in the stores in the study communities

\begin{tabular}{|c|c|c|c|c|}
\hline Food Item & Winnipeg (11 stores) & $\begin{array}{l}\text { Non-First Nations urban } \\
\text { centers in northern } \\
\text { Manitoba ( } 7 \text { stores) }\end{array}$ & $\begin{array}{l}\text { Communities with all- } \\
\text { weather roads (13 stores) }\end{array}$ & $\begin{array}{l}\text { First Nations communities } \\
\text { without all-weather roads } \\
\text { (6 stores) }\end{array}$ \\
\hline Skim milk (1 litre) & 100.0 & 100.0 & 38.5 & 16.7 \\
\hline Low-fat milk (2 litre) & 100.0 & 71.4 & 53.8 & 83.3 \\
\hline Fat-reduced milk (2 litre) & 100.0 & 100.0 & 100.0 & 100.0 \\
\hline Whole milk (4 litre) & 100.0 & 100.0 & 100.0 & 83.3 \\
\hline Lactose-free milk (1 litre) & 81.8 & 85.7 & 7.7 & 16.7 \\
\hline Chocolate milk (4 litre) & 90.9 & 85.7 & 69.2 & 66.7 \\
\hline Ground Beef & 100.0 & 100.0 & 84.6 & 33.3 \\
\hline Chicken Breast & 100.0 & 85.7 & 69.2 & 16.7 \\
\hline Chicken thighs & 90.9 & 85.7 & 53.8 & 16.7 \\
\hline Pork Chops & 100.0 & 71.4 & 61.5 & 33.3 \\
\hline Eggs & 100.0 & 100.0 & 100.0 & 100.0 \\
\hline Apple & 100.0 & 85.7 & 84.6 & 83.3 \\
\hline Banana & 100.0 & 85.7 & 84.6 & 83.3 \\
\hline Orange & 100.0 & 85.7 & 76.9 & 83.3 \\
\hline Grape & 90.9 & 85.7 & 76.9 & 66.7 \\
\hline Onion & 100.0 & 85.7 & 84.6 & 83.3 \\
\hline Tomatoes & 100.0 & 85.7 & 84.6 & 83.3 \\
\hline Potatoes & 100.0 & 85.7 & 84.6 & 83.3 \\
\hline Carrot & 90.9 & 85.7 & 69.2 & 83.3 \\
\hline Lettuce & 100.0 & 85.7 & 61.5 & 83.3 \\
\hline Energy Drink & 90.9 & 100.0 & 69.2 & 66.7 \\
\hline Potato Chips & 100.0 & 100.0 & 92.3 & 83.3 \\
\hline Pepsi, 2 Litre & 100.0 & 100.0 & 100.0 & 100.0 \\
\hline Pepsi, 12 Pack & 100.0 & 100.0 & 84.6 & 83.3 \\
\hline Wheat flour (10 kg) & 100.0 & - & 70.0 & 66.7 \\
\hline Coffee (930 gm) & 60.0 & - & 76.9 & 66.7 \\
\hline Sugar (2 kg) & 100.0 & - & 76.9 & 83.3 \\
\hline
\end{tabular}


Table 3: Average food prices (in Canadian dollars) across different geographic locations in Manitoba

\begin{tabular}{|c|c|c|c|c|}
\hline Food Item & Winnipeg (11 stores) & $\begin{array}{l}\text { Non-First Nations urban } \\
\text { centers in northern } \\
\text { Manitoba (7 stores) }\end{array}$ & $\begin{array}{l}\text { Communities with all- } \\
\text { weather roads (13 stores) }\end{array}$ & $\begin{array}{l}\text { First Nations communities } \\
\text { without all-weather roads } \\
\text { (6 stores) }\end{array}$ \\
\hline Skim milk (1 litre) & 1.55 & 1.56 & 2.23 & 2.65 \\
\hline Low-fat milk (1 litre) & 1.58 & 1.57 & 2.43 & 2.42 \\
\hline Low-fat milk (2 litre) & 3.31 & 3.45 & 3.82 & 4.12 \\
\hline Fat-reduced milk (1 litre) & 1.66 & 1.67 & 2.04 & 3.06 \\
\hline Fat-reduced milk (2 litre) & 3.34 & 3.48 & 3.86 & 4.99 \\
\hline Fat-reduced milk (4 litre) & 4.79 & 5.08 & 6.99 & 8.11 \\
\hline Whole milk (4 litre) & 5.25 & 5.60 & 4.43 & 8.56 \\
\hline Lactose-free milk (2 litre) & 5.32 & 5.70 & 5.84 & 6.15 \\
\hline Chocolate milk (4 litre) & 5.29 & 6.43 & 8.73 & 9.64 \\
\hline Ground Beef & 11.54 & 10.90 & 12.24 & 16.89 \\
\hline Chicken Breast & 14.50 & 17.45 & 17.17 & 21.99 \\
\hline Chicken thighs & 8.77 & 9.27 & 10.93 & 15.49 \\
\hline Pork Chops & 12.48 & 10.99 & 12.92 & 19.04 \\
\hline Eggs & 2.96 & 3.13 & 3.77 & 3.90 \\
\hline Apple & 3.36 & 4.36 & 5.66 & 7.41 \\
\hline Banana & 1.81 & 1.64 & 2.76 & 4.72 \\
\hline Orange & 3.52 & 3.45 & 4.65 & 3.80 \\
\hline Grape & 5.25 & 4.72 & 8.10 & 9.93 \\
\hline Onion & 1.83 & 2.93 & 2.92 & 3.17 \\
\hline Tomatoes & 3.94 & 5.17 & 6.54 & 10.86 \\
\hline Potatoes & 1.30 & 1.29 & 2.03 & 2.21 \\
\hline Carrot & 1.82 & 2.63 & 3.02 & 4.46 \\
\hline Lettuce & 1.84 & 2.20 & 2.37 & 2.58 \\
\hline Energy Drink & 2.70 & 3.09 & 3.36 & 3.75 \\
\hline Potato Chips & 3.39 & 3.39 & 4.57 & 5.72 \\
\hline Pepsi, 2 Litre & 2.42 & 2.33 & 3.34 & 8.80 \\
\hline Pepsi, 12 Pack & 5.57 & 5.88 & 7.61 & 20.25 \\
\hline Wheat flour (10 kg) & 17.01 & - & 22.84 & 35.34 \\
\hline Coffee (930 gram) & 17.58 & - & 21.09 & 26.12 \\
\hline Sugar (2 kg) & 3.58 & - & 4.89 & 6.97 \\
\hline
\end{tabular}


Table 4: Pairwise comparison of the average difference in food prices using Tukey-Kremar procedure for unequal sample size (in Canadian Dollars)

\begin{tabular}{|c|c|c|c|c|c|c|}
\hline Food Items & $\begin{array}{c}\text { Winnipeg VS } \\
\text { non-First Nations } \\
\text { urban centres }\end{array}$ & $\begin{array}{c}\text { Winnipeg VS } \\
\text { First Nations } \\
\text { communities with } \\
\text { access to all- } \\
\text { weather road }\end{array}$ & $\begin{array}{l}\text { Winnipeg VS } \\
\text { First Nations } \\
\text { communities with } \\
\text { no access to an } \\
\text { all-weather road }\end{array}$ & $\begin{array}{l}\text { Non-First Nations } \\
\text { urban centers VS } \\
\text { First Nations } \\
\text { communities with } \\
\text { access to an all- } \\
\text { weather road }\end{array}$ & $\begin{array}{l}\text { Non-First nations } \\
\text { urban centers VS } \\
\text { First Nations } \\
\text { communities with } \\
\text { no access to an } \\
\text { all-weather road }\end{array}$ & $\begin{array}{l}\text { First Nations } \\
\text { communities with } \\
\text { access to an all- } \\
\text { weather road VS } \\
\text { no access to an } \\
\text { all-weather road }\end{array}$ \\
\hline Skim milk (1 litre) & 0.01 & $0.68 * * *$ & $1.10^{* * *}$ & $0.67 * * *$ & $1.09 * * *$ & 0.42 \\
\hline Low-fat milk (1 litre) & -0.01 & $0.84 * * *$ & $0.84^{* *}$ & $0.85^{* *}$ & $0.85^{* *}$ & -0.01 \\
\hline Low-fat milk (2 litre) & 0.14 & 0.52 & $0.82 *$ & 0.37 & $0.68 *$ & 0.31 \\
\hline Fat-reduced milk (1 litre) & 0.14 & 0.51 & $1.65 * * *$ & 0.38 & $1.51 * * *$ & $1.31^{* *}$ \\
\hline Fat-reduced milk (2 litre) & 0.14 & 0.51 & $1.65 * * *$ & 0.38 & $1.15^{* * *}$ & $1.13^{* * *}$ \\
\hline Fat-reduced milk (4 litre) & 0.39 & $2.20 * * *$ & $3.32 * * *$ & $1.91 * * *$ & $3.03 * * *$ & $1.11^{*}$ \\
\hline Whole milk (4 litre) & 0.35 & $2.17 * * *$ & $3.31 * * *$ & $1.82 * * *$ & $2.96 * * *$ & $1.14^{*}$ \\
\hline Lactose-free milk (2 litre) & 0.48 & 0.52 & 0.93 & 0.14 & 0.45 & 0.31 \\
\hline Chocolate milk (4 litre) & 0.51 & $2.83 * *$ & $3.73 * * *$ & $2.32 * *$ & $3.21 * * *$ & 0.89 \\
\hline Ground Beef & -0.64 & 0.70 & 5.35 & 1.34 & $6.00 *$ & 4.65 \\
\hline Chicken Breast & 2.94 & 3.26 & $7.48^{*}$ & 0.3 & 4.54 & 4.22 \\
\hline Chicken thighs & -1.55 & 0.43 & 6.56 & 1.98 & $8.11^{*}$ & 6.13 \\
\hline Pork Chops & -1.55 & 0.43 & $6.56^{*}$ & 1.98 & $8.11^{*}$ & 6.13 \\
\hline Eggs & 0.16 & $0.80 * *$ & $0.94 * *$ & 0.64 & 0.78 & 0.14 \\
\hline Apple & 1.00 & $2.29 * * *$ & $4.04 * * *$ & 1.29 & $3.04^{* *}$ & 1.75 \\
\hline Banana & -0.18 & $0.96 * * *$ & $2.90 * * *$ & $1.14 * * *$ & $3.08 * * *$ & $1.97 * * *$ \\
\hline Orange & -0.70 & $1.23 *$ & 0.28 & 1.20 & 0.35 & -0.84 \\
\hline Grape & 0.01 & $3.38 * *$ & $5.21 * * *$ & $3.37 * *$ & $5.20 * * *$ & 1.83 \\
\hline Onion & 1.11 & 1.1 & 1.35 & -0.01 & 0.24 & 0.25 \\
\hline Tomatoes & 1.66 & $3.04^{*}$ & $7.35 * * *$ & 1.37 & $5.69 * *$ & $4.31^{* *}$ \\
\hline Potatoes & -0.1 & 0.73 & 0.91 & 0.75 & 0.92 & 0.18 \\
\hline Carrot & 0.81 & $1.21^{* *}$ & $2.64 * * *$ & 0.39 & $1.83 * *$ & $1.43^{* *}$ \\
\hline Lettuce & 0.36 & 0.53 & 0.74 & 0.17 & 0.35 & 0.21 \\
\hline Energy Drink & 0.37 & $0.65 * *$ & $1.04 * * *$ & 0.27 & 0.66 & 0.39 \\
\hline Potato Chips & 0.01 & $1.18^{* * *}$ & $2.33 * * *$ & $1.18^{* *}$ & $2.33 * * *$ & $1.15^{* *}$ \\
\hline Pepsi, 2 Litre & 0.08 & $1.10^{* *}$ & $7.52 * * *$ & $1.01^{*}$ & $7.44 * * *$ & $6.42 * * *$ \\
\hline Pepsi, 12 Pack & 0.31 & $2.04 *$ & $14.68^{* * *}$ & 1.73 & $14.37 * * *$ & $12.64^{* * *}$ \\
\hline Wheat flour (10 kg) & - & 5.83 & $18.21^{* * *}$ & - & - & 12.39* \\
\hline Coffee (930 gram) & - & 3.50 & $8.54 *$ & - & - & 5.02 \\
\hline Sugar (2 kg) & - & $1.31 * * *$ & $3.16 * * *$ & - & - & $1.85 * * *$ \\
\hline
\end{tabular}

Significance level: The *, **, and *** show that the average prices are significantly different using a 5 percent $(\mathrm{p}<0.05), 1$ percent $(\mathrm{p}<0.01)$ and 0.1 percent $(\mathrm{p}<0.001)$ significance level, respectively. The average food price difference, e.g. between Winnipeg and non-First Nations urban centers, was calculated as the average food price in Winnipeg minus the average food prices in non-First Nations urban centers. 


\section{Food prices}

The average prices of food across different geographic locations in Manitoba are given in Table 3. We provide here a brief discussion of the prices of some key foods.

\section{Milk}

The average milk prices in the First Nations communities (including communities that have access to an all-weather road) were significantly higher than the prices in Winnipeg and nonFirst Nations urban centers in northern Manitoba. Average prices of milk (for all container sizes and different fat content) in the First Nations communities with no access to an all-weather road were exceptionally high, even after taking into account the subsidies received through the Nutrition North Canada (NNC) program. For instance, the average price of a one-litre fatreduced carton of milk in First Nations communities with no access to an all-weather road was approximately 84 percent higher with the NNC subsidy and 181 percent higher without the subsidy as compared to the price in Winnipeg. First Nations communities with no access to an all-weather road, on average, paid between 63 percent and 69 percent more for the four-litre jug of milk than consumers in Winnipeg. There were very little or no difference in the average prices of milk between Winnipeg and non-First Nations urban centers in northern Manitoba.

Though the availability of lactose-free milk is quite limited in First Nations communities, the average price difference between Winnipeg and First Nations communities was not as high as the average price difference in regular milk. There was, on average, a maximum of about 23 percent difference in the prices of lactose-free milk between Winnipeg and First Nations communities. However, the average price of lactose-free milk is much higher than the price of regular milk of the same container size, and thus more likely unaffordable by most low-income families.

In Manitoba, although milk prices are regulated, the milk prices regulation currently applies only to one-litre carton milk and is geographically limited to within a 240 kilometer radius around Winnipeg and a 360 kilometer radius around Brandon. ${ }^{6}$ However, the majority of First Nations communities are located outside these regulated areas, thus effectively exposing them to higher milk prices.

\footnotetext{
${ }^{6}$ A retailer cannot charge more than the price specified by the Manitoba Milk Price Review Commission-e.g., a maximum of $\$ 1.71$ for one-litre whole milk in Winnipeg and Brandon. This price is adjusted every year in February based on the changes in the consumer price index and production costs of the previous year. Milk distributors or retailers can charge a transportation differential of 1 cent for every 30 kilometers for a distance up to 240 kilometers from Winnipeg and 360 kilometers from Brandon.
} 


\section{Fresh fruits and vegetables}

The prices of apples, bananas, and grapes were significantly more expensive in rural First Nations communities (with and without access to an all-weather road) as compared to both Winnipeg and non-First Nations urban centers. The average prices of apples, bananas, and grapes in rural First Nations communities without access to an all-weather road were 121 percent, 161 percent, and 89 percent higher than the prices in Winnipeg, respectively. As compared to the prices in First Nations communities with access to an all-weather road, bananas and apples were significantly more expensive in First Nations rural communities without access to an all-weather road. While there was no significant difference in the prices of onions and lettuce across all the different communities, tomatoes and potatoes were significantly more expensive in rural First Nations communities with and without access to an all-weather road. As compared to the average price in Winnipeg, tomatoes were 66 percent and 176 percent more expensive in First Nations with and without access to an all-weather road, respectively. There no significant difference in the prices of fruits and vegetables studied between Winnipeg and non-First Nations urban centers in northern Manitoba.

\section{Meat products}

Ground beef in rural First Nations communities without access to an all-weather road was significantly more expensive compared to Winnipeg and non-First Nations urban centers. The prices of chicken breasts and pork chops in rural First Nations communities with and without access to all-weather roads were significantly higher than in Winnipeg. The average prices of meat products were between 46 percent and 77 percent higher in rural First Nations communities without access to an all-weather road as compared to Winnipeg, or between 26 percent and 73 percent higher as compared to non-First Nations urban centers in northern Manitoba. Overall, the prices of meat products studied were not significantly different between Winnipeg and non-First Nations urban centers.

\section{Less nutritious food items}

There is a commonly held assumption that the prices of less nutritious or unhealthy food items are cheaper than healthy foods (Food Secure Canada, n.d.). However, as compared to Winnipeg or non-First Nations urban centers, the less healthy food items considered in this study were $a s$ expensive or even sometimes more expensive than healthy foods in First Nations communities. The average prices of all less healthy foods studied were significantly more expensive in First Nations rural communities with and without access to an all-weather road as compared to Winnipeg. The prices of less healthy food items studied were between 38 percent and 293 percent or between 21 percent and 277 percent more expensive in First Nations communities with no access to an all-weather road than in Winnipeg or non-First Nation urban centers, 
respectively. The price of Pepsi was exceptionally high in rural First Nations communities without access to an all-weather road where a two-litre container and 12 pack of Pepsi were 293 percent and 264 percent more expensive than in Winnipeg. There was also a significant price difference for all the less nutritious foods studied (except for energy drinks) between First Nations with and without access to an all-weather road. Table 4 summarizes a pairwise multiple comparison of the average food price differences across different communities using a TukeyKremar procedure for unequal sample size. Overall, about 57 percent and 77 percent of the food items presented in Table 5 were significantly more expensive in First Nations with and without access to an all-weather road as compared to Winnipeg, respectively. Forty percent of these food items were significantly more expensive in First Nations communities without access to an allweather road than in those with access to all-weather road.

\section{Determinants of food prices}

We ran a regression analysis using the Ordinarily Least Square (OLS) model to investigate the determinants of food prices in northern Manitoba. The results are presented in Table 5. Since not all food items studied were available in all the stores visited, it was not possible to construct a food price index and use that index as a dependent variable in our OLS model. Rather, we used the prices of selected food items as a dependent variable and ran several separate models. We used population size, access to an all-weather road, and distance from Winnipeg, which are all factors assumed to influence food price, as independent variables in our model. ${ }^{7}$

Our OLS estimates show that among the three variables considered, only lack of access to an all-weather road significantly influences food price. For instance, keeping population size and distance from Winnipeg at the same level, the model predicts that, compared to communities with access to an all-weather road, the average price of 2 litre (2 percent) milk and 2 litre Pepsi in First Nations communities with no access to an all-weather road is 1.27 times and 6.82 times higher, respectively. The effect of this barrier on food prices was significant across all the models estimated. Population size had no significant effect on food prices examined. Except for tomatoes, distance from Winnipeg had also no significant effect on the food prices studied.

\footnotetext{
${ }^{7}$ We also considered the number of stores in the community as an explanatory variable in our initial model. However, since all the First Nations communities without access to an all-weather road have only one store, there is a perfect collinearity between the number of store in the community and access to an all-weather road.
} 
Table 5: Estimates of determinants of food prices in northern Manitoba

\begin{tabular}{|l|c|c|c|c|c|c|}
\cline { 2 - 7 } \multicolumn{1}{c|}{} & $\begin{array}{c}\text { Milk (2L, 2 } \\
\text { percent, 37 } \\
\text { stores) }\end{array}$ & $\begin{array}{c}\text { Whole milk } \\
\text { (4 liter jug, } \\
\text { 36 stores) }\end{array}$ & $\begin{array}{c}\text { Bananas } \\
\text { (33 stores) }\end{array}$ & $\begin{array}{c}\text { Onion (33 } \\
\text { stores) }\end{array}$ & $\begin{array}{c}\text { Chips (35 } \\
\text { stores) }\end{array}$ & $\begin{array}{c}\text { Pepsi (37 } \\
\text { stores) }\end{array}$ \\
\hline Intercept & 3.640 & 6.000 & 2.920 & 2.580 & 4.208 & 2.470 \\
$(0.483)$ & $(0.734)$ & $(0.456)$ & $(1.511)$ & $(0.674)$ & $(0.624)$ \\
\hline Population size & $<0.001$ & $<0.001$ & $<0.001$ & $<0.001$ & $<0.001$ & $<0.001$ \\
& $(0.001)$ & $(0.001)$ & $(0.001)$ & $(0.001)$ & $(0.001)$ & $(0.001)$ \\
\hline Access to all- & $1.27 * * *$ & $1.806^{* * *}$ & $2.300 * * *$ & $4.670^{* * *}$ & $1.567 * * *$ & $6.822^{* * *}$ \\
weather roads & $(0.308)$ & $(0.494)$ & $(0.294)$ & $(1.039)$ & $(0.409)$ & $(0.399)$ \\
\hline Distance from & 0.001 & 0.015 & 0.002 & $0.051^{*}$ & $<0.001$ & 0.007 \\
Winnipeg & $(0.007)$ & $(0.001)$ & $(0.006)$ & $(0.021)$ & $(0.009)$ & $(0.008)$ \\
\hline Adjusted R-Squared & 38 & 53 & 74 & 63 & 47 & 91 \\
\hline
\end{tabular}

\section{Results of qualitative research and discussion of findings}

\section{Food availability, quality and accessibility}

For this study, we collected data on the availability and prices of selected food items in stores across different locations in Manitoba in order to compare the availability and affordability of foods. Our findings show that in First Nations rural communities with or without access to an allweather road, the availability of foods in the stores surveyed was very low as compared to Winnipeg or non-First Nations urban centers in northern Manitoba. This difference was particularly evident in the availability of skim milk, lactose-free milk, fresh meat products, and grapes. Timing plays a role in food availability, and several communities demonstrated low availability, or quality, of certain foods at particular times of the month or year. According to the information from focus group participants, stores in the First Nations rural communities, particularly those that have only one store, run out of most food items (milk especially) quite regularly. As one focus group participant from Wasagamack, Island Lake, stated: "During pay time, everyone in the community rushes to the store to get groceries but the store mostly runs out of some products and you have to wait two to three days to get them when the store is restocked.”

In addition to lack of availability, for rural First Nations communities especially in communities with no access to an all-weather road, the quality of the foods available in the store is another key challenge. Since it takes longer for a shipment to reach these fly-in communities, the quality of perishable food items deteriorates even before they reach store shelves. During transportation, some items, particularly perishable and frozen foods, are exposed to different temperature conditions thus leading to quality deterioration. There was considerable dissatisfaction among focus group participants with the quality of many of the food items 
available in the only grocery store in the communities. In the six focus group discussions held with mothers and community service providers, low quality of perishable foods was raised as one of the main problems in connection with grocery shopping. For example, one focus group participant in Lac Brochet said: "By the time fruits and vegetables arrive here they are not good... half of them are already bad. Spoilage is a big problem with fruits and vegetables. We do not have sales like they do in cities and towns. The only time we have a sale is when the product is out-dated."

Food availability in local stores, of course, does not guarantee access. Food prices, distance to the stores, and availability of local public transport are other main factors that determine accessibility. Our findings show that First Nations communities living in rural areas are paying significantly higher prices for most of the food items examined, whether they have access to an all-weather road or not. In all the focus group discussions, participants voiced deep concerns about food prices. As one participant from Wasagamack said "Milk is too expensive and not affordable. But we still buy it. We do not have any other choice. Just two bags of groceries costs about $\$ 300$. What we can afford here is just ground beef (mostly frozen) and rice.”

\section{Transportation costs and monopoly as drivers of food prices}

According to the Northern Food Prices Project Steering Committee (2003) report, freight/transportation costs contribute significantly to the high foods price in northern Manitoba, particularly in communities without access to an all-weather road. An online survey conducted by the NRG Research Group (2015) with retail managers in the northern Canada also showed that 73 percent of the managers who were interviewed believed that reducing freight rates would have the greatest impact on reducing the costs of groceries sold in their stores (NRG Research Group, 2015). While our study also shows that food prices in communities with no access to an all-weather road are significantly higher, we do not have data to directly examine the impact of transportation costs on food prices.

Our study also shows that First Nations rural communities that have access to an allweather road were paying much higher prices than non-First Nations living in urban centers in northern Manitoba. Most food prices in First Nations communities such as Chemawawin and Misipawistik were significantly higher than in Thompson or Flin Flon, yet these communities are located nearly halfway between Winnipeg (the main food distribution center) and Thompson or Flin Flon. This suggests that, in reality, transportation costs may play a much smaller role than what many perceive, in determining food prices in First Nations communities with access to an all-weather road. As one focus group participant in Cross Lake First Nations pointed out: "We have roads and food should not be that expensive here. I have a friend who lives in Gods Lake and their prices are really high. We are not isolated like that and it is not that far to drive to Thompson. Thompson is further [from Winnipeg] but they have lower prices than us.” 
Focus group participants in communities without access to an all-weather road stated that the reason food prices are very high in their community is because of the monopoly due to lack of competition between retailers and high cost of transportation because of their isolation or remoteness. When this study was conducted, about 67 percent of the First Nations communities visited had only one grocery store, which supports communities’ argument about lack of competition. As one focus the group participant from Lac Brochet indicated:

The North West Company buys milk in bulk. They get a big discount on that. Perimeter airline also gives them a discount. In addition to that, they also get a subsidy from the federal government. But when the milk gets here the price is tripled. Why is that? Because there is no competition.

A more puzzling issue that surfaced was the food price discrepancy between Opaskwayak Cree Nation (a First Nations community) and The Pas, even though they are located very near to each other geographically, and separated only by a bridge. Out of the 32 food items on our survey list that were available in stores in both communities, 24 food items (75 percent) were more expensive in Opaskwayak Cree Nation, while only 8 food items (25 percent) were more expensive in The Pas. To give an example, at the time of our survey, the prices of one and four litres of milk, and baby formula (12 x $385 \mathrm{ml}$ Enfamil) were \$1.62, \$5.29 and \$52.99 in The Pas, respectively, while the same quantity and brand were \$1.99, \$6.39, and \$64.99 in Opaskwayak Cree Nation, respectively.

Our finding that First Nations communities are paying a higher price for foods than nonFirst Nations urban centers in northern Manitoba, although they are located in very close proximity, is analogous with the conclusion of a recent study conducted in northern Ontario (Food Secure Canada, 2016). Furthermore, this Food Secure Canada study states that many First Nations communities in southern Canada experience food insecurity that greatly exceeds neighboring non-Indigenous cities and towns.

\section{Out of community shopping}

Although food prices in all First Nations communities were significantly higher than in non-First Nations urban centers in northern Manitoba, communities with access to an all-weather road have the option to drive to nearby towns or cities that offer more product choices with higher quality, lower prices, and more sales. Focus group participants in Chemawawin and Cross Lake First Nations revealed that shopping outside their communities is a very common practice.

As shopping outside the community involves travel and time costs, not all community members have the ability to shop outside their communities. As one focus group participant in Chemawawin stated "Some people always shop here because they do not have a car. They have no choice and they have to get their food here. They are mostly people on social assistance.” Furthermore, First Nations communities without access to an all-weather road have very limited options for shopping outside of their community during most of the year, except during the 
winter when the ice road opens. ${ }^{8}$ However, focus group participants in Wasagamack indicated that a shorter winter season and less snowfall than usual are making travelling on winter roads more problematic and unpredictable.

\section{Lack of transportation for local and out of community shopping}

All six focus group discussions held in the different First Nations communities consistently identified lack of access to transportation for food shopping as a key challenge for people who do not own their own vehicle. It is usually those on social assistance and young single mothers who are most affected. As is indicated in Table 1, the percentage of First Nations communities on social assistance ranges between 24 percent and 48 percent. The high costs of transportation add a further burden on family budgeting for these populations, whose social assistance incomes are generally low. As there is no access to public transportation, people's only options are to obtain a ride from family members and friends, or hire a taxi. The costs of transportation adds to the already high cost of food thus limiting out-of-community shopping.

Some of the challenges related to transportation are community specific. For instance, Wasagamack First Nations community faces two unique challenges in relation to accessing the local store and seasonal food availability. First, the Northern Store is located on a separate Island and during all seasons except for the winter every community member must pay for the boat taxi to the store. The second challenge is a seasonal lack of food availability. The Wasagamack First Nation community does not have its own airport and the Northern Store must transport its shipments by barge from St. Theresa Point, where the nearest airport is located. However, boat transportation is a challenge in fall and spring during freeze-up and ice break-up. Focus group participants in Wasagamack indicated that depending on the weather, there were times when most of the food items were unavailable in the local store for an extended period of time. Food prices also go up during certain times, as stated by a Wasagamack participant:

Every year during the break-up and freeze-up, the price of milk and other food products will go up and sometimes remain the same after the break-up and freeze-up. There is a time in a spring where milk price was as high as \$13.99 for a four-litre jug! We have no authority to ask the Northern Store to bring the cost down after the freeze-up and break-up.

\section{Implications of high food prices for First Nations communities}

Higher food prices negatively affect access to food, particularly for low-income families, and people on social assistance. All the mothers who participated in the focus groups said that for

\footnotetext{
${ }^{8}$ For instance, First Nations communities in Island Lake and Shamattawa shop in Norway House and Gillam during wintertime, respectively.
} 
families with children, meeting the households' demand for milk was a significant challenge. Additionally, they pointed to the high price of milk as the main barrier to accessing enough milk for their families.

Focus group participants also indicated that the inability to afford purchasing foods for their family is a source of constant stress, frustration, and anger which all have implications for mental health. One focus group participant from Cross Lake described the challenge of a neighbour as follows: "I know someone who has a hard time. When she run out of food she asks my parents. When she cannot get the help she is really frustrated and angry...that is probably one mother." Another said that "When you are not able to provide your children with milk either because you do not have enough money to buy it or there is no milk in the store it really hurts your feelings."

Most of the mothers in the focus groups recognized that low-income households (particularly those headed by single mothers and mothers on social assistance) with children frequently run out of food such as milk, requiring them to make a difficult choice between providing milk to their children versus other basic necessities. As one participant in Wasagamack stated:

What I usually do is sell out food, for example, ground beef for $\$ 25$, and that is enough to pay for my boat taxi to cross to the store [which costs $\$ 10$ for a return trip] and buy a four-litre jug of milk. That also affects what you have budgeted for a week. Selling something to get something else and that continues like a cycle. People sell pampers because they have to buy milk. And then they will be looking for pampers after few days. So it is an added stress, daily.

Focus group participants also linked the causes of diabetes in aboriginal communities to high food prices, as another Wasagamack participant stated:

I wonder why there is an epidemic of diabetes in Aboriginal communities. Because food is so expensive so they buy a big bag of spaghetti over milk. You know what I mean? And then like the whole grain stuff, the whole grain pasta is way more expensive than the big white spaghetti. A small amount of good stuff for higher prices and a large amount for less.

\section{The significance of traditional foods in combating food insecurity}

Focus group participants emphasized the importance of harvesting and consuming traditional foods for meeting their nutritional needs, in ways that also satisfies their traditional values. A recent study conducted in Norway House First Nations in northern Manitoba revealed that about 90 percent of the households involved in fishing and harvesting of traditional foods are food secure (Islam \& Berkes, 2016). When discussing the transition in their communities from food 
self-sufficiency on traditional foods to store bought processed foods, focus group participants spoke of rapid and profound changes, such as this Wasagamack participant:

The flip from traditional food to buying your food happened not that long ago. It happened in the early 1960s. It was a rapid change that created dependency overnight. It took less than ten years from complete self-sufficiency on traditional foods, no subsidy, to what we have now.

And another participant from the same community put it like this:

I do not remember drinking milk. Most of my days were in a bush. In my childhood, we ate wild food and I spent most of my time on a trap line. Now it is mostly canned food and that is what I think is making everybody sick. A lot of people are getting diabetes. I do not have diabetes . . . . I do not eat those canned foods. That is what I recommend. Eat wild food. Like my dad used to tell me: there is medicine in wild foods.

Although the trend of consuming traditional food has declined particularly among the younger generation (Council of Canadian Academies, 2014), some communities and families still practice hunting, fishing, and wild fruit harvesting, though the level of traditional food harvesting varies across different communities. Focus group participants provided several reasons for the decline in consumption of traditional foods. First, is the cost (e.g., fuel, equipment, transportation) that makes harvesting traditional foods unaffordable. Second, participants pointed to a growing scarcity of some traditional foods caused by expansion of hydro development and climate change. Studies have highlighted that global climate change and environmental contaminations of traditional food affects the availability, supply and safety of traditional foods (Guyot, Dickson, Paci, Furgal, \& Chan, 2006; Kuhnlien \& Chan, 2000). Clearly, several critical factors (e.g., dam developments for hydroelectric and mining activities) could contribute to the scarcity and lack of access to traditional foods. The third main reason highlighted by participants is a lack of knowledge regarding traditional practices, including what, where and when to harvest traditional foods, particularly among the younger generation. As one participant from Wasagamack said: "The white people brought in the bad foods. I remember when I was a kid we used to eat berries and wild fruits and that was what we snacked on. Now the kids do not even know what to eat." While another participant from the same community stated:

I think most of the people here would say their grandfathers had gardens. Like my father had lettuce, tomatoes, cabbages, potatoes, cornels and carrots. Why can't we do that? We had a big garden around our house. We were harvesting that even when it was raining. No question asked. That was how disciplined we were. Now we cannot even do that. 


\section{Conclusions}

This article examined the availability and prices of store-bought foods, and the implications of such factors on communities in northern Manitoba. An in-store price survey and six focus group discussions were used to collect data in 22 communities. Based on this empirical research, we conclude that in addition to limited availability of healthy foods, food prices in First Nations communities were significantly higher than in Winnipeg or non-First Nations urban centers. While the Nutrition North Canada program attempts to tackle the high food prices in northern communities with no access to an all-weather road, it does not sufficiently reduce prices of healthy foods to an affordable level. Addressing the lack of access to, and availability of, healthy foods (both store-bought and traditional foods) could have positive public health implications, protecting individuals in these communities from the negative mental and physical health effects of food insecurity, and inability to properly provide for their families.

The two main reasons for high food prices were 1) a monopoly and therefore lack of competition among retailers in the region; and 2) the high transportation costs faced by retailers in First Nations communities without access to an all-weather road. Although in some cases (in communities with no all-weather road) transport costs certainly led to higher food prices, it is not universal. For example, people living in Chemawawin, a First Nations community situated 450 kilometres from Winnipeg, pay significantly higher food prices than consumers in The Pas that is located 625 kilometres from the capital. Clearly, factors other than transportation play a major role, and rigorous quantitative analysis is required to better understand the determinants of food prices, and develop appropriate policies for addressing the elevated food prices in northern communities. Our findings also point to a need for more research to document, and better understand, the policy implications of existing food price discrepancies between First Nations and non-First Nations communities located in the same/similar geographic areas.

From a food security perspective, there are a number of policy implications emerging from this research. First, a policy change that could have immediate benefit would be to extend the current milk price regulations to include northern communities in Manitoba which could reduce milk prices by up to 38 percent. Secondly, creating economic opportunities as determined by the communities themselves to raise household income (purchasing power) could assist in addressing the food insecurity problem. Thirdly, since the lack of an all-weather road is the key determinant of food prices in northern Manitoba, in the long-term, one partial solution might be building road infrastructure for those communities where it is financially and environmentally feasible to do so, and, most importantly, if this is desired by the community. While these may be important short-term steps to help better ensure food security for those living in Indigenous communities, working directly with communities through meaningful consultation is absolutely necessary to understand how they would like to see issues of food access addressed, be it through transportation or other means.

Our research also revealed an important political dimension. It signaled the need for a more substantial and profound transformation that includes decolonizing food systems and 
building Indigenous food sovereignty. To decrease dependency on store-bought foods, focus group participants stressed the cultural and nutritional benefits of harvesting and eating traditional foods. Thus, it is important to ensure that Indigenous peoples have unimpeded access to their traditional geographical hunting, trapping, fishing, and harvesting areas, and that these areas be protected from development projects that lead to contamination of water, flora, and fauna is essential. Furthermore, it is also crucial to facilitate opportunities for inter-generational knowledge transfer in traditional hunting, harvesting, and cooking techniques within fields such as health and education to improve access to, and utilization, of traditional foods.

This leads to the need for a broader conversation beyond food security to focus more on Indigenous food sovereignty so that Indigenous peoples may self-determine their own food and surrounding political and economic systems (Coté, 2016; Kamal et al. 2015; Martens, Cidro, Hart, \& McLachlan, 2016; Morrison, 2011; People’s Food Policy Project, 2011). As Daigle (2017) demonstrates in the case of the nearby Anishinaabe communities (on Treaty 3 territory in Ontario, Canada), the protection, resurgence and regeneration of Indigenous foodways are critical to the processes of decolonization and self-determination; furthermore, this selfdetermination is "grounded in everyday practices of resurgence" (p.2) that are themselves embedded in everyday acts of resurgence of food practices.

\section{References}

Alfred, T. (2009). Colonialism and state dependency. Journal of Aboriginal Health, 5, 42-60.

Bruce, S. (2000). The impact of diabetes mellitus among the Metis of Western Canada. Ethnicity and Health, 5(1), 47-57.

Carter, S. A. (1993). Lost harvests: Prairie Indigenous reserve farmers and government policy. Montreal: McGill-Queen’s Native and Northern Series.

Chan, L., Receveur, O., Sharp, D., Schwartz, H., Ing, A., Fediuk, K., Black, A., \& Tikhonov, C. (2010). First Nations food, nutrition and environment study (FNFNES): Results from Manitoba. Prince George, BC: University of Northern British Columbia.

Cidro, J., \& Martens, T. (2014). Eating Indigenous in the City: The Limited Scope of Food Sovereignty for Indigenous People in Urban Contexts. International Journal on Biodiversity Watch, 55 (Fall/Winter), 53-64.

Corntassel, J. (2008). Toward sustainable self-determination: Rethinking the contemporary Indigenous-rights discourse. Alternatives, 33(1), 105-132.

Corntassel, J. (2012). Re-envisioning resurgence: Indigenous pathways to decolonization and sustainable self-determination. Decolonization: Indigeneity, Education \& Society, 1(1), 86-101. 
Coté, C. (2016). Indigenizing” food sovereignty. Revitalizing indigenous food practices and ecological knowledges in Canada and the United States. Humanities, 5(3), 57.

Council of Canadian Academies. (2014). Aboriginal food security in northern Canada: An Assessment of the State Knowledge, Ottawa, ON. The Expert Panel on the State of Knowledge of Food Security in Northern Canada, Council of Canadian Academies.

Daigle, M. (2017). Tracing the terrain of Indigenous food sovereignties. The Journal of Peasant Studies, 1-19. DOI: 10.1080/03066150.2017.1324423

Daschuk, J. (2013). Clearing the plains. Regina, SK: University of Regina Press.

De Schutter, O. (2012). Mission to Canada. Special rapporteur on the right to food, United Nations. Retrieved from https://foodsecurecanada.org/sites/foodsecurecanada.org/files/20120321_SRRTF_Aide-m percentC3 percentA9moire_Canada.pdf.

Food and Agriculture Organization of the United Nations [FAO]. (1996). Rome declaration on food security. Rome, Italy: UN.

Food and Agriculture Organization of the United Nations [FAO]. (2006). Policy Brief, June 2006, Issue 2, FAO’s Agriculture and Development Economics Division, Rome, Italy: UN. Retrieved from http://www.fao.org/forestry/131280e6f36f27e0091055bec28ebe830f46b3.pdf

Fieldhouse, P., \& Thompson, S. (2012). Tackling food security issues in indigenous communities in Canada: the Manitoba experience. Nutrition and Dietetics, 69(3), 217-221.

Food Matters Manitoba: http://www.foodmattersmanitoba.ca/

Food Secure Canada. (2016). Paying for nutrition: A report on food costing in the North. Retrieved from https://foodsecurecanada.org/sites/foodsecurecanada.org/files/201609_paying_for_nutritio n_fsc_report_final.pdf.

Food Secure Canada. (n.d.). The rising cost of food: A national food policy should focus on health and sustainability. Retrieved from https://foodsecurecanada.org/resourcesnews/news-media/cost-food-national-food-policy-should-focus-health-and-sustainability.

Glacken, J. B. (2008). Promising practices for food security. Draft Summary Report. First Nations and Inuit Health Branch, Health Canada, Ottawa.

Guyot, M., Dickson, C., Paci, C., Furgal, C., \& Chan, H. M. (2006). Local observations of climate change and impacts on traditional food security in two northern Aboriginal communities. International Journal of Circumpolar Health, 65(5), 403- 415.

Haman, F., Fontaine-Bisson, B., Batal, M., Imbeault, P., Blais, J. M., \& Robidoux, M. A. (2010). Obesity and type 2 diabetes in Northern Canada's remote First Nations com- munities: the dietary dilemma. International Journal of Obesity, 34(S2), S24-S31. 
Harris, R. C. (2002). Making Native Space: Colonialism, Resistance, and Reserves in British Columbia. Vancouver: University of British Columbia Press.

Health Canada. (2007). Eating Well with Canada's Food Guide - First Nations, Inuit and Métis, Retrieved from https://www.canada.ca/en/health-canada/services/food-nutrition/reportspublications/eating-well-canada-food-guide-first-nations-inuit-metis.html

Indigenous and Northern Affairs Canada (2016). First Nations community profile. Retrieved from http://fnp-ppn.aandc-aadnc.gc.ca/fnp/Main/Search/FNListGrid.aspx?lang=eng.

Islam, D., \& Berkes, F. (2016). Indigenous peoples’ fisheries and food security: a case from northern Canada. Food Security, 8(4), 815-826.

Johnson, J. S., Nobmann, E. D., Asay, E., \& Lanier, A. P. (2009). Dietary intake of Alaska Native people in two regions and implications for health: The Alaska Native Dietary and Subsistence Food Assessment Project. International Journal of Circumpolar Health, 68(2), 109-122.

Johnson, S. M., Martin, D. \& Sarin, C. (2002). Diabetes mellitus in the First Nations population of British Columbia, Canada. Part 3. Prevalence of diagnosed cases. International Journal of Circumpolar Health, 61(3), 260-264.

Kamal, A. G., Linklater, R., Thompson, S., Dipple, J. \& Committee, I. M. (2015). A recipe for change: Reclamation of Indigenous food sovereignty in O-PIPON-NA-PIWIN Cree Nation for decolonization, resource sharing, and cultural restoration. Globalizations, 12(4), 559-575.

Kuhnlein, H. V., \& Chan, H. M. (2000). Environment and contaminants in traditional food systems of Northern Indigenous Peoples. Annual Review of Nutrition, 20(1), 595-626.

Kuhnlein, H. V., Soueida, R., \& Receveur, O. (1996). Dietary nutrient profiles of Canadian Baffin Island Inuit differ by food source, season, and age. Journal of the American Dietetic Association, 96(2), 155-162.

Kwon Y-I, Apostolidis E, Kim Y-C, \& Shetty, K. (2007). Health benefits of traditional corn, beans and pumpkin; In vitro studies for hyperglycemia and hypertension management. Journal of Medical Food 10(2), 266-675.

MacDonald, D., \& Hudson, G. (2012). The Genocide question and Indian Residential Schools in Canada. Canadian Journal of Political Science, 45(2), 427-449.

Manitoba Keewantinowi Okimakanak Inc. https://www.mkonation.com/

Martens, T., Cidro, J., Hart, M., \& McLachlan, S. (2016). Understanding Indigenous food sovereignty through an Indigenous research paradigm. Journal of Indigenous Social Development, 5(1), 18-37.

McCallum, M. J. L. (2017). Starvation, experimentation, segregation, and trauma: Words for reading Indigenous health history. The Canadian Historical Review, 98(1), 96-113. 
Morrison, D. (2011). Indigenous food sovereignty - A model for social learning. In H. Wittman, A.A. Desmarais and N. Wiebe (Eds.), Food sovereignty in Canada: Creating just and sustainable food systems (pp. 97-113). Halifax: Fernwood Publishing.

Mosby, I. (2013). Administering Colonial Science: Nutrition Research and Human Biomedical Experimentation in Aboriginal Communities and Residential Schools, 1942-1952. Histoire sociale/ Social History, 46(91), 145-172.

Northern Food Prices Project Steering Committee. (2003). Northern food prices project report. Healthy Child Committee of Cabinet, Manitoba Government. Retrieved from https://www.gov.mb.ca/ana/food_prices/pubs/2003_northern_food_prices_report.pdf.

NRG Research Group. (2015). Northern food retail data collection and analysis. Retrieved from http://www.nutritionnorthcanada.gc.ca/eng/1424364469057/1424364505951.

Partridge, C. (2010). Residential schools: The intergenerational impacts on Aboriginal peoples. Native Social Work Journal, 7(1), 33-62.

People’s Food Policy Project. (2011). Resetting the table: A people’s food policy project.

Retrieved from: http://peoplesfoodpolicy.ca/policy/resetting-table-peoples-food-policyCanada.

Power, E. (2008). Conceptualizing food security for Aboriginal people in Canada. Canadian Journal of Public Health, 99(2), 95-97.

Reading, C. L., \& Wien, F. (2009). Health inequalities and social determinants of Aboriginal Peoples’ health. Prince George, BC: National Collaborating Centre for Aboriginal Health.

Redwood, D. G., Ferucci, E. D., Schumacher, M. C., Johnson, J. S., Lanier, A. P., Helzer, L. J., \& Tom-Orme, L. (2008). Traditional foods and physical activity patterns and associations with cultural factors in a diverse Alaska Native population. International Journal of Circumpolar Health, 67(4), 335-348.

Robidoux, M. A., Haman, F., \& Sentha, C. (2009). The relationship of the burbot (Lota lota L.) to the reintroduction of off-the-land foods in the Sandy Lake First Nation community. Biodemography and Social Biology, 55(1), 12-29.

Rudolph, K. R., \& McLachlan, S. (2013). Seeking Indigenous food sovereignty: Origins of and responses to the food crisis in northern Manitoba, Canada. Local Environment: The International Journal of Justice and Sustainability, 18(9), 1079-1098.

Simpson, L. (2011). Dancing on our Turtle’s Back: Stories of Nishnaabeg Re-Creation, Resurgence, and a New Emergence. Winnipeg, MB: Arbeiter Ring Publishing.

Socha, T., Zahar, M., Chambers, T., Abraham, R., \& Fiddler, T. (2012). Food security in a northern First Nations community: An exploratory study on food availability and accessibility. Journal of Aboriginal Health, 8(2), 5-14. 
Statistics Canada. (2011). National Household Survey profile 2011. Retrieved from http://www12.statcan.gc.ca/nhs-enm/2011/dp-pd/prof/index.cfm?Lang=E.

Szathmary, F. J., Ritenbaugh, C., \& Goodby, C. S. (1987). Dietary change and plasma glucose levels in Amerindian population undergoing cultural transition. Social Science and Medicine, 24(10), 791-804.

Tarasuk, V, Mitchell, A., \& Dachner, N. (2014). Household food insecurity in Canada, 2012. Toronto: Research to identify policy options to reduce food insecurity (PROOF). Retrieved from http://proof.utoronto.ca/.

Truth and Reconciliation Commission (2015). Truth and Reconciliation Commission of Canada: Calls to Action. Retrieved from: http://www.trc.ca/websites/trcinstitution/File/2015/Findings/Calls_to_Action_English2.pdf

The Indian Act. (1876). An Act to amend and consolidate the laws respecting Indians. Retrieved from: https://www.aadnc-aandc.gc.ca/DAM/DAM-INTER-HQ/STAGING/textetext/1876c18_1100100010253_eng.pdf.

Thompson, S., Gulrukh, A., Ballard, M., Beardy, B., Islam, D., Lozeznik, V., \& Wong, K. (2011). Is community economic development putting healthy food on the table? Food sovereignty in Northern Manitoba’s Aboriginal communities. Journal of Aboriginal Economic Development, 7(2), 15-40.

Young, T. K., Reading, J., Elias, J., \& O’Neil, J. D. (2000). Type 2 diabetes mellitus in Canada’s First Nations: Status of an epidemic in progress. Canadian Medical Association Journal, 163(5), 561-566.

Willows, N. C. (2005). Determinants of healthy eating in Aboriginal peoples in Canada. Canadian Journal of Public Health, 96(3), S32-S36. 